Citation: M.S. Fujii, J. Hüttmann, N. Kutscher, H. Friedrichs-Liesenkötter(2020) Participation?! Educational Challenges for Young Refugees in Times of the COVID-19 Pandemic. Media Education 11(2): 37-47. doi: 10.36253/me-9605

Received: August, 2020

Accepted: September, 2020

Published: December, 2020

Copyright:@2020M.S. Fujii, J. Hüttmann, N. Kutscher, H. Friedrichs-Liesenkötter. This is an open access, peer-reviewed article published by Firenze University Press (http://www.fupress.com/me) and distributed under the terms of the Creative Commons Attribution License, which permits unrestricted use, distribution, and reproduction in any medium, provided the original author and source are credited.

Data Availability Statement: All relevant data are within the paper and its Supporting Information files.

Competing Interests: The Author(s) declare(s) no conflict of interest.

\section{Participation?! Educational Challenges for Young Refugees in Times of the COVID-19 Pandemic}

\section{Partecipazione?! Sfide educative per i giovani rifugiati ai tempi della pandemia del COVID-19}

\author{
Michi S. FujiI ${ }^{1, \star}$, Jana HÜttmann ${ }^{2}$, Nadia Kutscher ${ }^{1}$, \\ HENRIKE FRIEDRICHS-LIESENKÖTTER ${ }^{2}$ \\ ${ }^{1}$ University of Cologne \\ ${ }^{2}$ Leuphana University Lüneburg \\ *Corresponding author. E-mail: michi.fujii@uni-koeln.de; jana.huettmann@leuphana. \\ de; nadia.kutscher@uni-koeln.de; henrike.friedrichs-liesenkoetter@leuphana.de
}

\begin{abstract}
This article focuses the educational settings in the everyday life of young refugees in the context of distance education under the circumstances of the COVID-19 pandemic in Germany. It explores dimensions and intensifications of education-related digital inequality during this period in formal and non-formal educational settings. Based on ethnographic interviews with teachers, young refugees and social workers, different dimensions of inequality as well as interrelations between informal (leisure), non-formal (child and youth welfare) and formal (school) educational contexts for empowering the educational participation of young refugees, especially regarding online learning, are discussed. The empirical data show that during the period of distance education the specific needs of young refugees are only taken into account to a limited extent and thus increasing risks of exclusion from education emerge. Lack of technical access, media expertise, language skills and personal support turn out to be major challenges in enabling educational participation of vulnerable groups such as young refugees. Therefore, educational policy at federal and national level in Germany needs to outline a scheme on how to meet these challenges by further developing nonformal as well as formal educational support structures.
\end{abstract}

Keywords: digital media, young refugees, COVID-19, school, child and youth welfare, distance education, online learning. 
rifugiati, soprattutto per quanto riguarda l'apprendimento online. I dati empirici mostrano che durante il periodo dell'istruzione a distanza le esigenze specifiche dei giovani rifugiati vengono prese in considerazione solo in misura limitata e quindi emergono rischi crescenti di esclusione dall'istruzione. La mancanza di accesso tecnico, competenza in materia di media, competenze linguistiche e supporto personale si sono rivelate sfide importanti per consentire la partecipazione all'istruzione di gruppi vulnerabili come i giovani rifugiati. Pertanto, la politica educativa a livello federale e nazionale in Germania deve delineare uno schema su come affrontare queste sfide sviluppando ulteriormente strutture di supporto educativo non formale e formale.

Parole chiave: digital media, giovani rifugiati, COVID-19, scuola, assistenza sociale di bambini e giovani, educazione a distanza, apprendimento online.

\section{THE COVID-19 PANDEMIC AND ITS IMPACT ON THE EDUCATIONAL PARTICIPATION OF YOUNG REFUGEES}

Over the last few months, the spread of the COVID-19 pandemic and related containment measures have deeply affected schooling. In all federal states in Germany, schools have been closed for weeks and in the ongoing pandemic, many pupils are excluded temporarily from schooling due to quarantine requirements. Schools face the demand to provide beneath face-to-face-teaching also online lessons and materials. Against this background, stakeholders in educational policy are called for perceiving and embracing the opportunities of digital learning (OECD, 2020). Political initiatives to promote digital learning are enforced like never before (BMBF, 2020). In dealing with the COVID-19 crisis, online learning formats in the context of home schooling and related tools (e.g. Zoom, MS Teams etc.) are experiencing unprecedented growth.

Based on the sudden shift from face-to-face teaching towards digitalized learning formats, it became apparent which impact the inconsistent situation of digitalization strategies in the federal states can have for educational participation of vulnerable groups. Educational participation not only as representation e.g. in school attendance but as being capable resp. becoming enabled to take part in educational practices such as learning, appropriation and coping with everyday life takes place performatively and goes beyond mere 'membership' (Herzmann \& Merl, 2017). It can be understood in a double sense: 1) «Participation in the sense of 'taking part in', i.e. 'being present'" and 2) "Participation in the sense of 'having a part or share in something', which can be related to concepts such as 'empowerment' and 'ownership' and refers to one's sense of being taken seriously and being able to make an impact» (Lysgard \& Simovska, 2016; Korntheuer, 2016). Insufficient technical equipment, lack of media expertise of teachers and parents as well as precarious domestic conditions are relevant determinants (Bitkom, 2020; Geier \& Brinkmann, 2020). Due to the federal structure of the educational system in Germany, there is no nationwide approach to implement online teaching formats (Bitkom, 2020). In the past, this has led to substantial differences in the organization of online learning arrangements in schools regarding media concepts, equipment and qualification of teachers. The absence of a nationwide approach also applies to developments in digitization in child and youth welfare, which as a nonformal education sector is equally relevant to participation processes such as providing support for children and families in coping with everyday life and schooling. Here, media education in child and youth residential care or family education, in parental counseling institutions or family care as well as support of participation in school by school social work play a crucial role to support educational participation, especially for vulnerable groups. Literature and research on different aspects of the COVID-19 crisis and its impact on refugees, e.g. within different countries and refugee camps indicates uneven effects of the pandemic in different countries and in particular for marginalized groups (Vaughan, 2020). In Germany, first empirical studies on existing inequalities and educational disadvantage in settings of distance education have come up (Bremm \& Racherbäumer, 2020; Eickelmann \& Gerick, 2020). As for the role of teachers in this context, «digital teacher competence and teacher education opportunities to learn digital competence are instrumental in adapting to online teaching during COVID-19 school closures» (König et al. 2020, p. 1). Nevertheless, existing studies before the COVID-19 crisis already indicate that social inequalities persist in the digital context (Iske \& Kutscher, 2020). Currently, the majority of German pupils have access to the necessary hardware at home and parents prove to be the most important resource for their support. However, further differentiations in educational participation and disadvantages remain unexplored, including a lacking focus on young refugees (Telekom Stiftung, 2020; Andresen et al. 2020, p. 10). But the question emerges if as a result of the current situation young refugees are increasingly depending on the resources available to 
them and have no or insufficient access to digital educational opportunities. Here the risk of aggravating educational disadvantages and exclusion for this group becomes relevant.

This raises the question to what extent the specific needs of young refugees and related requirements (such as target-group oriented language training, close supervision, coping with psychological stress, lack of technical equipment, etc.) are taken into account in the current educational situation. Among already existing challenges with regard to their participation in education (Lechner \& Huber, 2017), young refugees might experience intensifications of their disadvantages. Since many support services relevant for them had been temporarily reduced or moved to digital formats, limitations in accessing schooling can aggravate already existing disadvantageous starting conditions. Child and youth services, which are said to have the potential to bridge educational disadvantages (Kessl et al., 2004), are also currently limited in supporting young refugees. Warning statements indicate that even more young refugees than before would now be excluded from education (UNHCR, 2020). The central question therefore is: To what extent do young refugees have the opportunity to participate in school and high-quality (digital) education under the current conditions and which aspects are relevant for a possible increase in (digital) inequality?

Within the framework of the joint ethnographic research project «Educational Participation of Refugees in Digitalized Educational Arrangements» (BIGEDIB), funded by the German Federal Ministry of Education and Research (BMBF) teachers, child and youth welfare professionals and young refugees were interviewed about the current school situation and their daily life. This article provides first insights into the current educational situation of young refugees and the challenges they face.

\section{RISKS OF INEQUALITY REPRODUCTION IN THE CONTEXT OF DIGITAL MEDIA}

In educational settings, digital media are discussed as means for the self-directed acquisition of knowledge and skills (Kutscher \& Kreß, 2018). Thus, they are regarded as important for promoting participation and equal opportunities for socially disadvantaged groups such as young refugees (Bitkom, 2018). Education policy in the context of schools in Germany - and increasingly also in child and youth welfare (cf. BMFSFJ, 2020) - focusses on promoting learning with digital media and the corresponding transfer of (media) skills (e.g. the DigitalPakt Schule - BMBF, 2019). This raises the question, which potentials and limitations schools face in terms of promoting the participation of disadvantaged groups in the context of digitalization processes. For some time, digitalization processes are attributed to have a positive influence on the further development of schools (Bitkom, 2018). However, critical assessment can also be found regarding the realization of this transformation process, e.g. regarding the provision of adequate technical equipment and related conceptual and political support measures (Fraillon et al., 2014). Also, Al-Hujran, Aloudat, Al-Hennawi and Ismail (2013) came to the conclusion that the success of online learning is highly dependent on how institutions are addressing key challenges such as awareness about its benefits and possible resistance from students and educators regarding the use of online learning methods whereas the structural inequalities or disadvantages are not coming into view.

In Germany about one third of all pupils in eighth grade do not have sufficient digital computer and information-related skills (Eickelmann et al., 2019). Computer and information-related skills differ significantly between young people with and without migration background (Eickelmann et al., 2019, p. 374). In addition, according to the «Monitor Digitale Bildung» less than half of the teachers interviewed assume that digital media can support under-performing pupils and thus promote educational participation (Schmid et al., 2017). These examples show that the problem of digital inequality (Kutscher, 2019) and lack of participation in education thus also exists concerning digitalization in schools but has so far received little empirical attention.

Besides the PISA surveys (OECD, 2019), other research indicates that schools are not sufficiently able to compensate for educational disadvantages (Kessl et al., 2004; Brake \& Büchner, 2011; Skorsetz et al., 2020), due to inconsistencies between formal structures and requirements on the one hand and informal (family) resources on the other hand (Henrichwark, 2009). Moreover, locating the working on overcoming educational inequalities mainly in schools by reproducing the "classroom-as-container» discourse (Leander, Philips \& Taylor, 2010) ignores the causes, conditions and entanglements of educational disadvantages and potentially contributes to the reproduction of institutional exclusion processes (Kutscher, 2019).

The situation of young refugees introduces a variety of challenges to the educational context of school, as discussed above. Up to now, there is a lack of research on the educational participation of young refugees and especially on the importance of digital media and their relevance in their formal or non-formal educational contexts. 
However, initial research on informal educational contexts indicates that digital media and especially the smartphone as a means of (trans-)national self-positioning have an important orientational function for young refugees (Kutscher \& Kreß, 2018). Thus, digital media can promote to develop and experience agency while coping with settling in the receiving society (FriedrichsLiesenkötter \& Müller, 2018). However, the «mediarelated skills of young refugees vary according to their availability of social, cultural and economic capital» (Kutscher \& Kreß, 2018, p. 7). Since digital spaces are not detached from power structures, these types of capital play a role in the reproduction of digital inequality with corresponding consequences for social participation options in the aforementioned institutional frameworks (Kutscher, 2019, p. 384).

Therefore, it seems necessary to take into account the interplay of different educational settings and modalities (Rauschenbach et al., 2004) while researching the educational participation of young refugees in the context of digitalization. Against this background, the ethnographic joint research project «Educational Participation of Refugees in Digitalized Educational Arrangements» (duration 2019 - 2022) examines from a trans-organisational perspective the young refugees' subjective abilities and requirements as well as the institutional conditions in non-formal (child and youth welfare), formal (school) and informal (leisure, family) educational contexts. In a multi-sited ethnography (Falzon, 2009), young refugees aged between 12 to 24 years are being followed in their various living contexts. Practices (Schatzki, 2002) in which digital media are involved are focused by participant observations in private, school and child and youth welfare contexts. The participants were selected according to different criteria such as country of origin, residence permit status, length of stay in the receiving country, language skills, media and educational experience, socio-economic background, unaccompanied or accompanied by relatives, different forms of youth welfare services, gender and age. In the sample, seven female and thirteen male young refugees from Syria, Albania, Kosovo, Moldova, Guinea, Eritrea, Afghanistan, Iraq and Iran were represented. During the current field phase, the effects of the COVID-19 pandemic did become apparent from March 2020 onwards as an issue in interviews and field discussions. The findings presented are based on interview data from the period March to April 2020 with seven young people from Afghanistan, Iran, Albania, Guinea and Syria, aged between 16 and 24 years who are living in Germany since two to nine years, three social workers, four teachers and one legal guardian. As some of the participants in the research could not be contacted during the lockdown period, not all participants in the project could be interviewed in this field phase. In semistructured interviews, questions were asked every one to four weeks about how the everyday school life of the young refugees currently proceeds, what changes have occurred, to what extent difficulties have arisen from the changes and how they are being dealt with. The interpretation of the interviews is based on Grounded Theory Methodology (Strauss \& Corbin, 1996). The bigger part of the interviews and ethnographic conversations were conducted by phone due to lockdown restrictions and some of them audio-recorded, some documented by field notes. ${ }^{1}$

\section{CHANGES AND CHALLENGES IN THE CONTEXT OF DURING THE COVID-19 PANDEMIC}

\subsection{Distance Education and Online Learning - Changes in Everyday School Life}

In the interviews and discussions, all participants report that communication between pupils and teachers has shifted to online formats as a result of school closures. Differences become apparent in the individual efforts and varying degrees of success of teachers in establishing accessibility and continuous contact with the young refugees. While some of the young refugees report that they were in permanent contact with their teachers while working on tasks, teachers report that they had difficulties in staying in contact with their pupils. The contact between teachers and parents or educators in residential youth welfare institutions took place mainly by e-mail and was primarily based on questions and feedback from teachers on how the pupils handle the tasks. The pupils received tasks and weekly plans with the request to return them to the teachers within a certain period of time after completion. The concrete implementation of this digital task distribution varied in detail. Personal e-mails or e-mail distribution lists of the respective classes, learning platforms and school portals such as Anton or IServ and smartphone messengers, such as WhatsApp, were used for this purpose. Some of the teachers reported about efforts to supervise students and being available for exchange on possible questions as a support structure for coping with learning tasks provided online. These offers, which were usually not obligatory for the pupils, were realized via video conferences, phone calls, e-mails and learning platforms. Across all schools, teachers were confronted with an abundance of online learning opportunities that were increasingly available and free of charge through school 
licenses. The teachers in our interviews perceived these digital offers as an occasion or necessity to «familiarize themselves with the most diverse possibilities» and to «further appropriate» (teacher Peter). For the pupils it became apparent that they were called upon to learn much more independently, as they had to structure the tasks on their own.

\subsection{Inequality Dimensions in Distance Education}

The educational disadvantages reported in the participating sample differ: Some of the refugees were coping well with school closures, whereas others had fundamental difficulties in being able to participate in digital teaching at all. In general, difficulties regarding the use of digital media in class already existed before the COVID-19 pandemic, such as unequal media expertise among students when working with office programs on the computer, but the pandemic situation increased these problems. The interviews reveal four central dimensions in which the educational disadvantages of digital education for young refugees became apparent.

Inequalities in technical access to digital media represent the first dimension. The processing of digitally sent homework assignments and participation in online learning formats in the context of homeschooling requires technical equipment such as laptop or computer, software and stable internet access. These prerequisites were often not available for the young refugees; in particular, equipment (e.g. computer/notebook and printer) was lacking. Even though the pupils often own a smartphone, this proved to be insufficient for processing the digitally sent homework. This becomes apparent in the report of a vocational college teacher whose class consists mainly of young refugees:

The pupils in my class for pre-vocational training simply do not have a computer at home. At most they have their smartphone. So if I would send them an assignment as a PDF file, some colleagues, my colleague has done this for his English class, the pupils would open the PDF file and have to work on the assignment and then the question occurs: 'How do I get this content, that I have here on my smartphone in digital form, on to a piece of paper?' We would simply print this PDF file at home, edit it, scan it and then send it back, but the pupils just don't have these possibilities. (Teacher Oliver)

It is evident that Oliver's pupils do not have the technical equipment to process the digital work assignments in the way they are expected to. The fact that «at most they have their smartphone» is described by the teacher as not sufficient for task processing. Instead, the computer is mentioned as a necessary device. With the expectation of printing, editing, scanning and sending it back again an explicit reference is made to working steps that go beyond the scope of a smartphone. The phrase "we would simply" expresses a difference in the possibilities between himself response a 'community of normality' (expressed by the "we») and the refugees who obviously are excluded from that normality. Although one option for the young refugees could be to print out the digital homework, for example in copy shops, this is only mentioned by the teachers but not as an option by the refugees. This suggests the assumption that the effort and costs of printing out the digitally sent homework could represent an obstacle. Other interviewees confirmed that the smartphone's features for digital task processing (e.g. text markers) were considered insufficient. In a direct comparison, the teenager Yusuf emphasizes the advantages of the notebook, where «the sentences are larger» and «everything is on one screen». With the smartphone, on the other hand, he considers it a hindrance to have to "always scroll down or up» and that the display switches off very often due to the screen lock. Another problem mentioned in this context is that teachers were not always aware of the fact that some of their students could not meet the necessary technical requirements. Thus, those students were in jeopardy of being left behind. However, this knowledge seems to be necessary to compensate for technical access difficulties. Furthermore, technical access proved to be not only relevant for the processing of tasks, but also to participate in digital counseling offers from teachers to support their students, e.g. via Zoom meetings, as the social worker Erim points out.

Even if technical access is available, the second dimension of inequality is the limited expertise in media use and the associated usage difficulties. This is how Susanne, a teacher at a comprehensive school, perceived differences between young refugees and their classmates with regard to pre-pandemic times. She describes a stronger familiarity and a higher knowledge in dealing with digital media among the non-refugee-classmates:

Regarding them (refugee students) you realize that they have been much less in touch with computers. This becomes obvious in situations when they just sit by idly and participate a little but not completely. I have actually never communicated via Iserv (learning management system) with them. I don't think it works really well there. So you can tell they drop out a bit. (Teacher Susanne)

Susanne describes being dependent on the use of digital media for participating in school, as an aggravating momentum for inequality «because they (young 
refugees) are of course much less used to working with digital media and so on». She observed that the young refugees in her class «find it even more difficult to cope with the tasks they are given». It remains unclear where these ascriptions of difference and less experience of the young refugees she speaks about and the «of course» are coming from.

Difficulties in dealing with digital media or communication with school and teachers were also reflected in the statements of the young refugees. Haias says he is «fed up with this laptop». Since on the one hand his laptop does not function sufficiently for using the IServ online learning platform and on the other hand he cannot edit texts with his smartphone, he uses his smartphone and laptop in parallel, which he describes as very challenging:

I do log in and then somehow I had to download and then all of a sudden this whole app kicked me out of IServ. And then I was not able to enter into it again. I was so worried. I thought: 'No, if my smartphone again/ if I cannot enter into IServ with my smartphone, then I will be really, (Haias)

Haias expresses his concern, «not to be able to keep up». Even though it remains unclear at this point whether technical deficits of the app or lack of media knowledge of the young person are the reason, it becomes clear that the responsibility for successful participation remains individually with Haias and his ability to handle the (more or less working) digital media: It is not the teacher who is regarded as responsible for ensuring access to teaching content on IServ, but the young person himself and it is him who has to bear the consequences in case of difficulties. For some young refugees even basic digital communication with teachers was problematic. Saad describes writing an e-mail to his teacher as a challenge, because he has no experience with this kind of communication.

B: This [writing an e-mail to the teacher] that is complicated. I have my mistakes there [...] It's just that I can't just send it. I don't even know how to write it.

I: That means you don't know what to write?

B: No it's not that, I don't know [...] I know what to write, but I don't know never (.) how do I have to send and write? I never did it before. (Saad)

The difficulty mentioned above means that he cannot receive any support in writing an e-mail for questions regarding school as he has difficulties already in the basic requirement of writing e-mails. Likewise, Amidou reports about difficulties in the context of dealing with the task to write a curriculum vitae which he received by e-mail from a teacher due to a lack of media knowledge («Because I have never done it before»). In addition to this homework, he describes challenges on the IServ learning management system and is not satisfied with his technical equipment. He has a laptop, but not a word processing program. The fact that programs such as OpenOffice are freely available is not mentioned, which suggests a lack of knowledge of alternative programs. This makes it clear that even if digital media are available and online learning does not fail because of the equipment, the young people face difficulties in coping with tasks, which often cannot be overcome without further personal support.

Thirdly, limited language skills also prove to be an obstacle to participate in the digital school life. It is obvious that young refugees are confronted with language barriers depending on the length of their stay in Germany and their acquired language skills. One of the responsibilities of schools is to ensure language support and acquisition. For this, close supervision is necessary, which, however, was hardly given under the conditions of the COVID-19 pandemic and school closures. Because of the lack of language skills, some of the pupils felt overstrained if they had to carry out tasks in German language on their own and without sufficient explanations. Regarding the difficulties in German language acquisition in the special classes for refugee students, teacher Oliver tells about the difficulties:

With them it's like that: Especially the ones in basic education classes need considerable support for the acquisition of German, they simply cannot speak German. And giving them assignments would not only confront them with technical obstacles, they simply need/ well they need intensive support from a teacher. And this by far is not possible. Thus, self-organized learning was unthinkable. Absolutely no way. Teacher Oliver)

The quote illustrates that one aspect of educational disadvantage beyond the "technical obstacles» is the knowledge of the German language, which is relevant for «self-organized learning». However, since the pupils in the special classes were only just beginning to acquire the German language and «simply cannot speak German", they were excluded from doing the digitally sent homework without further explanation and counsel. The necessary intensive supervision of the pupils, which used to take place in the face-to-face setting in the schools, was no longer available. It was simply not possible for Oliver to implement this support also in a digital form because of the increased effort required as he mentions elsewhere. In this context, it becomes clear how relevant personal contact with the teacher is and how the lack 
of this contact can be excluding from participation in online learning.

The fact that for participating in online learning settings, however, young refugees often lacked the resources of care and support in language acquisition in the private sphere, as e.g. their parents also often lacked sufficient knowledge of German, characterizes the fourth relevant dimension of inequality: Insufficient personal support systems (family, teachers, other caregivers) for helping to understand and implement the digital school tasks as well as coping with media access problems. Younger refugees like all younger pupils need close guidance in learning processes. In the case of the refugees, the parents often spoke only little or no German at all. Therefore, they could not support their children in the preparation of their homework. Thus, they also could not act as contact persons for questions of content or handling with German-language technical applications. In addition, structural problems were mentioned, such as a cramped living situation of the family, which made it difficult to participate in the digital school life from home. The young refugees therefore became the «sufferers» (teacher Markus) of the switch from the face-to-face teaching to digital communication and online learning in times of the COVID-19 pandemic. This was increasingly the case when it came to unaccompanied minor refugees. Since they had no local family support, developing self-organization skills proved to be vital. Social worker Daniel describes this for the young people he cares for: «There is a lot of self-organization that schools expect from them and that the young people themselves tell the teachers their needs, their problems and their questions».

Here, however, it is important to differentiate between young refugees who live in residential care and thus receive permanent socio-pedagogical support and those already living in their own homes with reduced pedagogical backing. Support by youth welfare profes- sionals can be helpful, but it cannot always guarantee self-organization:

I have experienced that this is hard [...]. I work with one young man, who just moved into his own flat. But of course he had no internet first, that has to be registered and installed. So for some time he had no Wi-Fi and therefore he missed some of the curriculum. And he also missed out on telling this to his teacher in time, so that he ended up receiving the lowest score three times. (Social Worker Daniel)

The problem described above points to the relevance of linking the two systems of child and youth welfare and school (e.g., to discuss problems together and identify solutions) to ease and overcome difficulties of the young refugees. Regarding the school closures, unaccompanied refugees also described the challenge of feeling left alone. School, as Amidou's statements shows, has been one relevant space for his social integration, which was no longer the case: «So it's okay if (school) starts again, because you are not so lonely then, so you do more, not just sitting alone in your room all day». Since there was no connection with his family who are not in Germany this loneliness seemed to be even more precarious.

Considering the dimensions of inequality for young refugees in the current context of distance education, these can be systematized with reference to the capabilities approach (Robeyns, 2005, p. 98; Kutscher, 2017). The capabilities approach as «broad normative framework for the evaluation and assessment of individual wellbeing and social arrangements» (Robeyns, 2005, p. 94) can therefore provide an orientation to find out about substantive freedoms (capabilities) that are accessible for those interviewed.

The missing or limited individual factors (language skills or expertise in media use) and structural (resources such as social framework and infrastructure) condi-

Table 1. Dimensions of Digital Inequality in the Context of Distance Education and Online Learning for Young Refugees.

\begin{tabular}{|c|c|c|c|}
\hline \multicolumn{2}{|c|}{ Individual factors } & Infrastructure & Social framework \\
\hline Limited language skills & Limited expertise in media use & $\begin{array}{c}\text { Lack of technical equipment and } \\
\text { access }\end{array}$ & $\begin{array}{c}\text { Insufficient personal support } \\
\text { systems }\end{array}$ \\
\hline
\end{tabular}

$\Downarrow$

Consequences of limited capabilities for the realization of educational participation

\begin{tabular}{llll}
\hline - Problems of understanding & - Insufficient media related skills & - Limited access to learning & - Mostly unaccompanied \\
German sufficiently & to process tasks & material & homeschooling \\
- Aggravated or impossible & - Overstraining occurs when & - Structural obstacles & - Loss of guided or structured \\
processing of tasks & shifting the responsibility for & for processing tasks and & learning processes \\
\hline
\end{tabular}


tions presented in the table above thus have far-reaching consequences for the unequal participation of young refugees (Kutscher, 2017, p. 210). Teacher Oliver summarizes the current situation of inequality as follows:

I regret in this / this is a general assessment, this current situation/ so let's say an educational gap, okay? There are educationally advantaged and disadvantaged young people, in my view it sadly happens that this current situation ensures that this gap simply increases. And that (.) makes me think and makes me aware of this crisis very drastically. (Teacher Oliver)

The ethnographic interviews also document that in one refugee reception center school, educational offers were completely cancelled due to a lack of alternatives. In other institutions, the young refugees were only provided with homework for German language acquisition, but not included in the regular digital school life. Difficulties for these young refugees to re-enter the classroom, both in terms of content and socially, are to be expected, not only because of their initial situation, but also because of the reduced or non-existent involvement in complementary educational opportunities during a rather long period of time.

\subsection{Coping Possibilities for Young Refugees in Times of Distance Education}

The dimensions of inequality identified in table $1-$ limited language skills, limited expertise in media use and insufficient personal support systems as well as lack of technical equipment and access - can result in powerful exclusion mechanisms. However, the field research also indicates that some of the young refugees succeeded in overcoming or mitigating their disadvantaged schooling situation. The efforts of the young people's caregivers, e.g. guardians, teachers and social workers, played an important role here and were of great importance for the expansion of the young refugees' chances of achieving their educational goals, e.g. by bridging the lack of technical equipment. For example, some teachers and social workers printed out school materials, sent them by post or brought them personally to the students. Other caregivers compensated the young refugees' lack of expertise in media use by intensive support, e.g. installing software on the notebook and explaining computer programs. In view of missing family support, difficulties of self-organization in completing school assignments were compensated for by regular contact and personal discussions between the professionals and the young refugees. The example of the social worker Jan shows the importance of close coordination between school and child and youth welfare services: In order to find out whether additional support for the young people with regard to grades and school-leaving qualifications was necessary under the school closures of COVID-19, he kept up constant contact with the responsible teaching staff and the school social worker. The contact initiated by him was also used by the teachers themselves, who contacted him to support and ask about the students concerned. Reasons for this contact were for example that teachers «cannot make contact themselves» with the young people and wanted to check if assigned tasks had been implemented or pass on information and feedback on homework. The establishment of such cross-institutional cooperation via social workers and teachers indicates the relevance of transorganisational perspectives for enabling participation in (distance) education and online learning.

On an individual level, sufficient knowledge of the German language as well as media-related skills and knowledge on the part of the young refugees turned out to be means of enabling them to promote their own participation in view of the distant schooling situation. The young refugees did this by using the communication channels provided by the schools and also by using other digital media in the processing of digital school assignments (e.g. internet research and YouTube videos for homework). These pupils were actively able to seek help themselves and network with fellow pupils or educators. Social (relationships), material (technical equipment) and cultural (skills, knowledge) capital were thus essential resources to compensate for the disadvantaged situation caused by the pandemic. Regarding the compensation of limited (family) social capital, institutionally available resource-enhancing relationships with skilled workers as «linking social capital» (Szreter \& Woolcock, 2004) were also relevant (Kutscher, 2017, p. 209).

\section{IMPLICATIONS FOR ENABLING EDUCATIONAL PARTICIPATION OF YOUNG REFUGEES IN ONLINE LEARNING AND OTHER FORMS OF DISTANT EDUCATION}

In view of the changes in schooling under the conditions of the COVID-19 pandemic and especially during times of lockdown or exclusion from face-to-face-class, data from ethnographic interviews with young refugees and pedagogues show central dimensions of the impairment of young refugees' educational participation. It becomes apparent that the specific needs of this heterogeneous target group under the conditions of a digitalized everyday school life at a distance are only, if at all, 
hardly taken into account. Thus, an immense risk of educational exclusion becomes apparent. While digital education arrangements are considered as compensation for the reduced presence formats, it is shown that this solution can aggravate digital inequality issues.

The ethnographic observations show that compensation for these mechanisms is largely achieved through non-digital formats and social relationships that make alternative resources available. The subjective abilities of the young refugees also represent a resource that, depending on the available capital (or capabilities), vary widely in their availability. The institutions (schools, child and youth welfare services) and actors (teachers, social workers) play a central role in this process, but depending on how they reflect the situation and compensate for it, this is shaped in very different ways. Thus, under the conditions of the COVID-19 pandemic, the success of young refugees' participation in education depends on individual decisions and is highly contingent.

Against this background, a state or nationwide agreement is needed on how to meet the challenges mentioned above by structural support systems. In addition to the provision of the technical prerequisites for participation in distance education and online learning, teachers as well as social workers need support in the creation and the usage of digital services, which are oriented towards the needs of the young refugees. Pedagogues in schools as well in as in child and youth welfare services require knowledge about the situation to support the (specific) needs of these pupils. Furthermore, they need the time and conceptual possibilities of adapting learning formats accordingly. In addition, close coordination via regular contact and exchange between child and youth welfare services and schools is necessary in order to ensure mutual awareness of current needs and challenges the pupils are facing. This would make it possible to communicate and work through the current problems and to make the online learning offers available to the young people and prevent educational exclusion. In this way, opportunities for digital participation in education under the given conditions could be further developed - not only - for young refugees.

\section{REFERENCES}

Al-Hurjan, O., Aloudat, A., Al-Hennawi, H. \& Ismail, H. N. (2013). Challenges of E-learning Success: The Student Perspective. Proceedings of the 2013 International Conference on Information, Business and Education Technology (ICIBET 2013), 1197-1205. https:// doi.org/10.2991/icibet.2013.226
Andresen, S., Lips, A., Möller, R., Rusack, T., Schröer, W., Thomas, S. \& Wilmes, J. (2020). Erfahrungen und Perspektiven von jungen Menschen während der Corona-Maßnahmen. Universitätsverlag Hildesheim. https://doi.org/10.18442/120

Bitkom (2018). Digitale Bildung- Handlungsempfehlungen für den Bildungsstandort Deutschland: Positionspapier- Neuauflage 2018. bitkom. https://www. bitkom.org/sites/default/files/file/import/FirstSpirit1515141793223180103-Positionspapier-Digitale-Bildung-Neuauflage.pdf

Bitkom (2020). Schul- und Weiterbildung in der Corona-Krise. https://www.bitkom.org/sites/default/ files/2020-04/20200402_bitkom-stellungnahme_akuter-handlungsbedarf-schul-und-weiterbi.pdf

BMBF (2019). Wissenswertes zum DigitalPakt Schule. https://www.bmbf.de/de/wissenswertes-zum-digitalpaktschule-6496.html

BMBF (2020). Karliczek: In Zeiten von Corona fördern wir digitales Lernen wie noch nie zuvor. https://www. bmbf.de/de/karliczek-in-zeiten-von-corona-foerdernwir-digitales-lernen-wie-noch-nie-zuvor-11453.html

BMFSFJ (2020). Referentenentwurf des Bundesministeriums für Familie, Senioren, Frauen und Jugend vom 05.10.2020. Entwurf eines Gesetzes zur Stärkung von Kindern und Jugendlichen (Kinder- und Jugendstärkungsgesetz - KJSG).

Brake, A. \& Büchner, P. (2011). Bildung und soziale Ungleichheit. Kohlhammer.

Bremm, N. \& Racherbäumer, K. (2020). Dimensionen der (Re-)Produktion von Bildungsbenachteiligung in sozialräumlich deprivierten Schulen im Kontext der Corona-Pandemie. DDS - Die Deutsche Schule, 112(16), 202-215. https://doi.org/10.5281/zenodo.3922063

Eickelmann, B. \& Gerick, J. (2020). Lernen mit digitalen Medien. Zielsetzungen in Zeiten von Corona und unter besonderer Berücksichtigung von sozialen Ungleichheiten. DDS - Die Deutsche Schule, 112(16), 153-162. https://doi.org/10.31244/9783830992318.09

Eickelmann, B., Bos, W., Gerick, J., Goldhammer, F., Schaumburg, H., Schwippert, K., Senkbeil, M. \& Vahrenhold, J. (Eds.) (2019). ICILS 2018 \#Deutschland - Computer- und informationsbezogene Kompetenzen von Schülerinnen und Schülern im zweiten internationalen Vergleich und Kompetenzen im Bereich Computational Thinking. Waxmann. https://kw.uni-paderborn.de/fileadmin/fakultaet/ Institute/erziehungswissenschaft/Schulpaedagogik/ ICILS_2018_Deutschland_Berichtsband.pdf

Falzon, M.-A. (2009). Multi-sited Ethnography. Ashgate Publishing Limited. 
Fraillon, J., Ainley, J., Schulz, W., Friedman, T. \& Gebhardt, E. (2014). Preparing for Life in a Digital Age. The IEA International Computer and Information Literacy Study International Report. https://doi. org/10.1007/978-3-319-14222-7

Friedrichs-Liesenkötter, H. \& Müller, F. (2018): Die Bedeutung digitaler Medien für Jugendliche mit Fluchterfahrung. Migration und Soziale Arbeit, 40(4), 316-324. https://content-select.com/de/portal/media/ view/5c0802f8-6f6c-4243-9da6-42aeb0dd2d03

Geier, B. \& Brinkmann, M. (2020). Lehrkräfte und digitale Bildung in Zeiten von Covid-19. https://www.gew.de/ aktuelles/detailseite/neuigkeiten/lehrkraefte-und-digitale-bildung-in-zeiten-von-covid-19/

Henrichwark, C. (2009). Der bildungsbezogene mediale Habitus von Grundschulkindern [Docotoral dissertation, Bergische Universität Wuppertal]. http://elpub.bib.uni-wuppertal.de/servlets/ DocumentServlet?id=1025

Hujran, O., Aloudat, A., Al-Hennawi, H. \& Ismail, H. (2013). Challenges to E-learning Success: The Student Perspective. Atlantis Press. https://doi.org/10.2991/icibet.2013.226

Iske, S. \& Kutscher, N. (2020). Digitale Ungleichheiten im Kontext Sozialer Arbeit. In N. Kutscher, F. Siller, T. Ley, A. Tillmann, U. Seelmeyer, \& I. Zorn (Eds.), Handbuch Digitalisierung und Soziale Arbeit (pp. 115-128). Beltz. https://www.researchgate.net/publication/339229497_ Handbuch_Soziale_Arbeit_und_Digitalisierung

Kessl, F., Kutscher, N., Otto, H.-U. \& Ziegler, H. (2004). Bildungsprozesse im sozialen Kontext unter dem Aspekt der Bedeutung des Sozialraums für das Aufwachsen von Kindern und Jugendlichen: Expertise zum 8. Kinder- und Jugendbericht der Landesregierung Nordrhein-Westfalen. Universität Bielefeld. http://www.aba-fachverband.org/fileadmin/user_ upload/user_upload\%202010/fachpolitik/Bildungsprozesse\%20im\%20sozialen\%20Kontext_BI.pdf

König, J., Jäger-Biela, D. J. \& Glutsch, N. (2020). Adapting to online teaching during COVID-19 school closure: teacher education and teacher competence effects among early career teachers in Germany. European Journal of Teacher Education, 43(4), 1-15. https://doi. org/10.1080/02619768.2020.1809650

Korntheuer, A. (2016). Die Bildungsteilhabe junger Flüchtlinge. Faktoren von Inklusion und Exklusion in München und Toronto. Waxmann. https://www.ssoar. info/ssoar/handle/document/66861

Kutscher, N. (2017). Geflüchtete als Zielgruppe medienpädagogischer Arbeit in der digitalisierten Gesellschaft. In S. Eder, C. Mikat \& A. Tillmann (Eds.), Software takes command, (pp. 203-217). kopaed Verlag.
Kutscher, N. (2019). Digitale Ungleichheit als Herausforderung für Medienbildung. DDS - Die Deutsche Schule, 111(4), 379-390. https://doi.org/10.31244/ dds.2019.04.02

Kutscher, N. \& Kreß, L.-M. (2018). The Ambivalent Potentials of Social Media Use by Unaccompanied Minor Refugees. Social Media \& Society, 4(1), 1-10. https://doi.org/10.1177/2056305118764438

Leander, K. M., Philips, N. C. \& Taylor, H. K. (2010). The Changing Social Spaces of Learning: Mapping New Mobilities. Review of Research in Education, 31(1), 329-394. https://doi.org/10.3102/0091732X09358129

Lechner, C. \& Huber, A. (2017). Ankommen nach der Flucht. Die Sicht begleiteter und unbegleiteter junger Geflüchteter auf ihre Lebenslagen in Deutschland. DJI e.V. https://www.dji.de/veroeffentlichungen/literatursuche/detailansicht/literatur/25854-ankommen-nachder-flucht.html

Lysgaard, J. A. \& Simovska, V. (2016). The significance of 'participation' as an educational ideal in education for sustainable development and health education in schools. Environmental Education Research, 22(5), 613-630. https://doi.org/10.1080/13504622.2015.102 9875

OECD (2019). Balancing School Choice and Equity: An International Perspective Based on Pisa. OECD Publishing. http://www.oecd.org/publications/balancingschool-choice-and-equity-2592c974-en.htm

OECD (2020). Education responses to covid-19: Embracing digital learning and online collaboration. https:// read.oecd-ilibrary.org/view/? ref $=120 \_120544$ 8ksud7oaj2\&title=Education_responses_to_Covid-19_Embracing_digital_learning_and_online_collaboration

Rauschenbach, T., Leu, H., Lingenauber, S, Mack, W., Schilling, M., Schneider, K. \& Züchner, I. (2004). Konzeptionelle Grundlagen für einen Nationalen Bildungsbericht: Non-formale und informelle Bildung im Kindes- und Jugendalter. BMBF. https://d-nb. info/971374708/34

Robeyns, I. (2005). The Capability Approach: a theoretical survey. Journal of Human Development, 6(1), 93-114. https://doi.org/10.1080/146498805200034266

Schatzki, T. R. (2002). The site of the social: a philosophical account of the constitution of social life and change. Pennsylvania State University Press.

Schmid, U., Goertz, L. \& Behrens, J. (2017). Monitor Digitale Bildung: Die Schulen im digitalen Zeitalter. Bertelsmann Stiftung. https://doi.org/10.11586/2017041

Skorsetz, N., Bonanati, M. \& Kucharz, D. (Eds.) (2020). Diversität und soziale Ungleichheit. Herausforderungen an die Integrationsleistung der Grundschule. 
VS-Verlag für Sozialwissenschaften. https://doi. org/10.1007/978-3-658-27529-7

Strauss, A. \& Corbin, J. (1996). Grounded Theory: Grundlagen Qualitativer Sozialforschung. Beltz.

Szreter, S. \& Woolcock, M. (2004). Health by association? Social capital, social theory, and the political economy of public health. International Journal of Epidemiology, 33(4), 650-667. https://doi.org/10.1093/ije/ dyh013

Vaughan, A. (2020). An uneven pandemic. New Scientist, 246(3277), 8-9. https://doi.org/10.1016/S02624079(20)30704-1

Telekom Stiftung (2020). "Schule zu Hause“ in Deutschland. Bestandsaufnahme im Corona-Lockdown aus Perspektive der Schüler/-innen und Eltern. https:// www.telekom-stiftung.de/sites/default/files/files/ media/publications/Ergebnisbericht-Homeschooling. pdf-

UNHCR (2020). Während COVID-19-Pandemie brauchen vertriebene Kinder mehr Unterstützung denn je. https://www.unhcr.org/dach/de/42555-waehrend-covid19-pandemie-brauchen-vertriebene-kinder-mehrunterstuetzung-denn-je.html 